\title{
Kohtuuhintaisen asumisen hajanainen kokonaisuus
}

Elina Sutela, Sampo Ruoppila, Jarkko Rasinkangas \& Jutta Juvenius

Artikkelissa tarkastellaan, miten asumisen kohtuuhintaisuutta määritellään suomalaisessa asuntopolitiikassa. Määrittelyssä erotetaan kolme näkökulmaa: normatiivinen, kuluttajavalintoja painottava ja asuntojen hallintamuotoihin perustuva. Tutkimusaineiston muodostavat hallitusohjelmat 2007-2019 sekä vuonna 2019 voimassa olleet asuntopolitiikkaa ja asumisen etuuksia käsittelevät ohjelmalliset linjaukset, lait ja aiesopimukset sekä kirjallisia lähteitä täydentävät asiantuntijahaastattelut.

Johdanto

Suomalainen asuntopoliittinen keskustelu on täynnä puhetta asumisen kohtuuhintaisuudesta ja kohtuuhintaisesta asumisesta, mutta lähes aina ilman kunnollista - jos ylipäätään minkäänlaista - käsitteen määrittelyä. Siksi tarkastelemme tässä artikkelissa, miten asumisen kohtuuhintaisuutta voidaan määritellä, miten asuntopoliittiset linjaukset ovat sitä määritelleet ja miten käsitettä tulkitaan asuntopolitiikan toteuttamisessa. Pohdimme myös, miten asiaa voi jatkossa selkeyttää.

Asumisen hinta on noussut kotitalouksien tuloja nopeammin suurissa ja keskisuurissa kaupungeissa kautta maailman (Anacker 2019; FEANTSA \& The Fondation 
Abbé Pierre 2019; OECD 2019). Kotitalouksille asumisen kalleus heijastuu esimerkiksi toimeentulovaikeuksina ja asumisvalintojen eriarvoistumisena. Kaupunkialueilla se voi muun muassa tyrehdyttää muuttoliikettä ja vaikeuttaa työvoiman saatavuutta. (esim. Gabriel \& Painter 2020.) Asumisen kalleus on nykyään pienituloisten kotitalouksien ohella laajasti myös keskiluokan ongelma. OECD-maissa asuminen on keskituloisissa kotitalouksissa eniten kasvanut menoerä vuoden 2008 finanssikriisin jälkeen (OECD 2019).

Asuntojen hintojen ja vuokrien kasvu suurimmilla kaupunkiseuduilla sekä kehityksen yhteiskunnalliset seuraukset herättävät huolta myös Suomessa $(\mathrm{mm}$. Tarkastusvaliokunta 2018; valtioneuvosto 2019b). Asumisen kalleus vaikeuttaa varsinkin pienituloisten, pääkaupunkiseudulla asuvien ja vuokralla asuvien toimeentuloa (Kauppinen, Hannikainen-Ingman, Sallila \& Viitanen 2015; Mukkila \& Saikkonen 2018; Ilmarinen \& Kauppinen 2018). Pienituloisten omistusasuminen on vähentynyt ja Helsingin seudulla myös keskituloisilla kotitalouksilla on vaikeuksia löytää tulotasoaan vastaavia omistusasuntoja (Saikkonen, Hannikainen, Kauppinen, Rasinkangas \& Vaalavuo 2018). Asuntojen hintojen erilaistumisen vauhdittama asuinalueiden sosioekonominen segregaatio on niin ikään herättänyt huolta (Kortteinen \& Vaattovaara 2015; Tarkastusvaliokunta 2018). Asumisen kohtuuhintaisuus onkin tärkeä, usein ilmaistu tavoite suomalaisessa asuntopolitiikassa (Tarkastusvaliokunta 2018; valtioneuvosto 2019b). Se on myös yksi kriteeri Suomea velvoittavissa kansainvälisissä, riittävän asumistason ja asumisoikeuksien toteutumista koskevissa sopimuksissa (Un Habitat 2009).

Asumisen kohtuuhintaisuuden tai kohtuuhintaisen asumisen käsitteiden määrittelyyn tai soveltamiseen on kuitenkin kiinnitetty Suomen asuntopoliittisessa keskustelussa niukasti huomiota. Jatkuva tulkinnanvaraisuus aiheuttaa väärinymmärryksiä ja vaikeuttaa sekä keskustelua tavoitteista että keinoista, joilla niihin voidaan pyrkiä (vrt. Granath Hansson \& Lundgren 2018). Sinänsä tällainen epäselvyys ei ole epätavallista, sillä asuntopolitiikan poliittis-ideologinen pohja ja sisällölliset muutokset heijastuvat myös käytettyihin määritelmiin, käsitteisiin ja retoriikkaan (vrt. Whitehead 1991). Asuntopolitiikka on Suomessa yleisesti ottaen ollut muille poliittisille tavoitteille alisteista ja tempoilevaa, vaikkakin kausittain aktiivista (Juntto 1990; 2001). Ruonavaara (2013) on kuvaillut Suomen asuntopoliittista järjestelmää markkinaehtoisuutta painottavaksi malliksi, jossa omistusasumisella on hallitseva ja sosiaalisella asuntotuotannolla residuaalinen rooli, ja jossa asuntopolitiikka ajatellaan usein sosiaalipolitiikan osaksi. Suomen perustuslaki ei takaa jokaiselle oikeutta asuntoon opetuksen tai sosiaali- ja terveyspalveluiden tavoin, vaan julkisen vallan tehtäväksi on määritelty edistää jokaisen oikeutta asuntoon ja tukea asumisen omatoimista järjestämistä (suomen perustuslaki 731/1999, 16 § \& 19 §; Hyötyläinen 2019, 40). Suomeen sopiikin hyvin Torgensenin (1987) kuvaus asuntopolitiikan roolista "huojuvana pilarina hyvinvointivaltion pohjalla". 
Tässä artikkelissa tarkastelemme, miten asumisen kohtuuhintaisuutta määriteltiin Suomen asuntopolitiikassa 2010-luvun lopulla sekä valtakunnallisella tasolla että kolmessa suuressa kaupungissa, Helsingissä, Tampereella ja Turussa. Esittelemme seuraavaksi tutkimuskirjallisuuden pohjalta luomamme teoreettisen viitekehyksen, jota hyödynnämme asumisen kohtuuhintaisuuden määritelmien tunnistamisessa, jäsentämisessä ja erottelemisessa. Analysoimme artikkelissa myös kohtuuhintaisuuden epäselvästä määrittelystä juontuvia, politiikan toteuttamiseen liittyviä ongelmia ja ristiriitoja sekä pohdimme, miten tilannetta voitaisiin parantaa.

Kolme näkökulmaa asumisen

kohtuuhintaisuuden määrittelyyn

Asumisen kohtuuhintaisuus (eng. housing affordability) on moniulotteinen ja siksi hankala käsite sekä tutkimuksessa että politiikassa. Sille ei ole tutkimuskirjallisuudessakaan yhtä vakiintunutta määritelmää tai mittaustapaa (Hancock 1993; Gabriel ym. 2005; Stone 2006; Haffner \& Heylen 2011; Bramley 2012; Ezennia \& Hoskara 2019), vaan sillä viitataan eri yhteyksissä eri asioihin, kuten tuloeroihin, kotitalouksien asuntolainakelpoisuuteen, kuluttajavalintoihin asuntomarkkinoilla tai asumisen hintaan vaikuttamiseen asuntopolitiikalla (Quigley ja Raphael 2004, 191-192). Käsitteen tyydyttävä määritteleminen ja mittaaminen vaativat usean tekijän - kuten asumistarpeiden, perhekoon ja asuntojen hallintasuhteen - huomioimista (Maciennan \& Williams 1990, 9; Hancock 1993; Gabriel ym. 2005; Stone 2006; Stone ym. 2011; Ezennia \& Hoskara 2019). Kohtuuhintaisuuteen kytkeytyy joukko mutkikkaita ja ytimeltään poliittisia kysymyksiä, kuten riittävä elintaso, asumistarpeet tai hyväksyttävä asumismenojen taso (vrt. Gabriel ym. 2005, 20; UN Habitat 2009). Erilaiset näkökulmat määrittelyyn ja ongelmiin (esim. pidetäänkö ongelmana tulojen pienuutta, asuntojen puutetta vai kumpaakin) johtavat erilaisiin politiikkavaihtoehtoihin (Hancock 1993, 129-132; Gabriel ym. 2005, 17; Anacker 2019, 5-8.)

Olemme jäsentäneet tutkimuskirjallisuuden pohjalta kolme keskeistä näkökulmaa asumisen kohtuuhintaisuuden määrittelyyn: normatiivisen, kuluttajavalintoja painottavan ja asuntojen hallintamuotoihin perustuvan. ${ }^{1}$ Käytännön asuntopolitiikassa eri näkökulmien mukaisia toimenpiteitä yhdistellään eri painotuksin (vrt. Doling 1997).

\section{Normatiivinen näkökulma}

Normatiivisessa näkökulmassa asumisen kohtuuhintaisuus määritellään kotitalouksien tulojen ja asumismenojen välisenä suhteena. Näkökulma tarkastelee

1 Olemme rajanneet kategorisoinnin ulkopuolelle keskustelun pitkän ja lyhyen aikavälin kohtuuhintaisuudesta (ks. esim. Haffner \& Heylen 2011) ja asuntojen hankitaan liittyvistä kysymyksistä (ks. tarkemmin Gabriel ym. 2005). Emme myöskään käsittele asuntojen tuotantokustannusten ja luovutushintojen näkökulmaa (Glaeser \& Gyourko 2003). 
asumista osana perustarpeita ja asumisen hintaa suhteessa käsityksiin siitä, minkälaiset resurssit kotitalous tarvitsee yhteiskunnallisesti hyväksyttävän elintason saavuttamiseen. Normatiivinen määritelmä edellyttää kannanottoa vähintään kolmeen seikkaan: asumisen laatuun ja hintaan sekä kotitalouden tuloihin. Näistä pyritään määrittelemään yksi tai useampi standardi eli raja-arvo, jota ei saa ylittää tai alittaa. Näkökulma on yleinen esimerkiksi yhteiskuntatieteissä asumisen eriarvoisuutta ja köyhyyttä koskevassa tutkimuksessa. (Maciennan \& Williams 1990, 9; Hancock 1993, 129; Bramley 1994, 105; 2012, 134; Gabriel ym. 2005; Stone ym. 2011; Smith 2012, 8; Ezennia \& Hoskara 2019.) Asumistukia voidaan pitää näkökulman käytännön sovelluksina, joilla saatetaan myös määritellä "virallinen" kohtuuhintaisuuden raja (vrt. Hancock 1993, 133).

Asumisen kohtuuhintaisuutta voidaan tästä näkökulmasta mitata monin tavoin (ks. Ezennia \& Hoskara 2019), joista tavanomaisimpia ovat tulo- ja meno-osuudet sekä asumismenojen jälkeen käteen jäävät tulot (Bramley 2012). Esimerkiksi Eurostat ja UN Habitat arvioivat asumiskustannukset kohtuuttomiksi, jos ne ylittävät 40 prosenttia kotitalouden käytettävissä olevista tuloista (UN Habitat 20o9; Eurostat 2014). Usein kohtuullisena rajana pidetään myös 25 tai 30 prosentin osuutta (stone ym. 2011). Osuuksia on sovellettu myös Suomessa pienituloisuutta ja alueellisia tuloeroja tarkastelevissa tutkimuksissa (Kauppinen ym. 2015; Ilmarinen \& Kauppinen 2018) ja niitä voi seurata esimerkiksi Tilastokeskuksen tulonjakotilastolla (svT 2020). Myös liikepankit soveltavat samankaltaista mittaustapaa arvioidessaan asuntolainojen hakijoiden maksukykyä. Osuuksia käytetään myös yleisemmin asumisen hinnan kotitalouskohtaisina indikaattoreina, asettamatta selkeitä kohtuullisuuden rajoja (Hulchanski 1995). Osuuksien käyttöä on kritisoitu siitä, että raja-arvojen perustelut ovat usein puutteellisia, eivätkä ne huomioi paljonko kotitaloudelle jää absoluuttisesti tuloja käytettäväksi (Hulchanski 1995; Stone ym. 2011). Joidenkin tutkijoiden mukaan osuuksia voidaan kuitenkin käyttää tietyin varauksin (Bramley 2012).

Käteen jäävien tulojen mittaaminen perustuu kotitalouden absoluuttisesti käytettävissä oleviin tuloihin. Asumismenot oletetaan ensisijaiseksi menoeräksi, ja tarkastelun kohteena on, riittävätkö tulot niiden jälkeen muiden kohtuullisiksi määriteltyjen tarpeiden kattamiseen. (Hancock 1993; Gabriel ym. 2005, 25-27; Stone ym. 2011.) Näkökulma muistuttaa köyhyysrajojen määrittelyä, minkä yksi sovellus ovat viite- ja minimibudjetit (Lehtinen \& Aalto 2018; Mukkila \& Saikkonen 2018). Minimibudjetteja voidaan soveltaa myös asumisen kohtuuhintaisuuden mittaamiseen (Padley \& Marshall 2019).

Normatiivisessa näkökulmassa jaettu näkemys "kohtuullisesta" ja "riittävästä" ja niiden operationalisointi mitattavaksi suureiksi on keskeistä. Sitä pidetään 
usein julkisen vallan tehtävänä (esim. Maciennan \& Williams 199o, 9). Ilman selkeää näkemystä, mitä mitataan ja miten, normatiivinen näkökulma jää vaille konkretiaa. ${ }^{2}$

\section{Kuluttajavalintoja painottava näkökulma}

Kuluttajavalintoja painottavan näkökulman mukaan asumiskustannusten kohtuullisuudessa on kysymys kotitalouksien valinnoista ja arvostuksista asuntomarkkinoilla. Asumisesta maksettu hinta heijastelee sitä, paljonko kotitalous pystyy tai haluaa asumisesta maksaa tai millaiset ominaisuudet se valitsee kulutusmahdollisuuksiensa rajoissa. Näkökulma on yleinen taloustieteellisissä tutkimuksissa. (Bramley 1994, 3; Laakso \& Loikkanen 2004, 253-254; Stone ym. 2011, 17-18; Smith 2012, 8.) Näkökulman mukaan ei ole mielekästä mitata asumiskustannusten kohtuullisuutta standardilla tai antaa asumiselle ulkoisia arvotuksia (stone 2006, 159 \& Stone ym. 2011, 17-18), vaan sopiva asumisen hinta määrittyy käytännössä asuntomarkkinoilla. Mahdollisten interventioiden tavoitteena on ideaali markkinatilanne, jossa asuntojen kysyntä ja tarjonta kohtaavat. (Laakso \& Loikkanen 2004, 253-259; Smith 2012, 8.) Asumisen kalleus suosituissa sijainneissa tai tietynlaisissa asunnoissa kuvastaa niiden korkeaa arvostusta, johon pienituloiset kotitaloudet voivat reagoida tinkimällä asuntojen koosta tai muista ominaisuuksista tai valitsemalla maksukyvylleen sopivia asuntoja muista sijainneista (Antikainen, Laakso, Lönnqvist, Pyykkönen \& Soininvaara 2017, 10; Eerola, Lyytikäinen \& Saarimaa 2012).

Näkökulman keskeinen kritiikki on, ettei hyödykkeiden - eli tässä tapauksessa asuntojen - vaihtaminen markkinoilla ja niiden hinta vielä riitä selventämään, mikä on hyödykkeelle riittävä tai kohtuullinen taso (esim. Andersson 1993). Asumisen riittävä laatu ja kohtuullinen hinta ovat viime kädessä poliittisia kysymyksiä, eivät johdettavissa kuluttajien toiminnasta markkinoilla. ${ }^{3}$ Olennaista on, missä määrin kotitalous pystyy vaikuttamaan asumistaan koskeviin valintoihin vai onko asuminen vain seurausta rajallisista mahdollisuuksista (esim. Hancock 1993). Esimerkiksi Stone (2006, 159; Stone ym. 2011, 17-18) on esittänyt, että asumisen kohtuuhintaisuutta voidaan ajatella kuluttajavalintoihin perustuvana kysymyksenä vasta tietyn tulojen kynnysarvon ylittymisen jälkeen.

\section{Asuntojen hallintamuotoihin perustuva näkökulma}

Tässä näkökulmassa asumisen kohtuuhintaisuudella viitataan tiettyihin asuntojen hallintamuotoihin, joiden suhteellisesta edullisuudesta pyritään huolehtimaan. Asuntopoliittisessa keskustelussa asumisen kohtuuhintaisuus

2 Eri mittareista ja niihin liittyvistä huomioista ks. tarkemmin muun muassa Hancock (1993), Hulchanski (1995), Gabriel ym. (2005) Stone ym. (2011), Haffner ja Heylen (2011),Bramley (2012) ja Ezennia \& Hoskara (2019).

3 Poliittisen taloustieteen piirissä on käyty suurta keskustelua siitä, miten asunnot ovat viime vuosikymmeninä ennen näkemättömällä tavalla "hyödykkeistyneet" osaksi kansainvälisiä kiinteistömarkkinoita, ja miten niiden vaihtoarvo on irtautunut niiden käyttöarvosta (ks. esim. Madden \& Marcuse 2016). 
rinnastetaan toistuvasti hinnoiltaan säänneltyyn asuntokantaan tai -tuotantoon (esim. Stone 2006, 154). Tästä kantaa nimitetään kontekstista riippuen sosiaaliseksi (social housing) ja kohtuuhintaiseksi (affordable housing). Selvyyden vuoksi käytämme tästä asuntokannasta Stonen $(2006,154)$ tapaan yhteistä nimitystä alle markkinahintainen asuntokanta (below-market housing).

Alle markkinahintainen asuntokanta koostuu tavallisesti vuokra-asunoista, mutta siihen voi kuulua myös esimerkiksi omistusasuntoja, osuuskuntaasuntoja tai asumisoikeusasuntoja. Tuotantoa tuetaan julkisin varoin ja tavoitteena ovat markkinahintoja edullisemmat asumiskustannukset. Varsinkin sosiaalinen asuntotuotanto kohdennetaan tarveperustaisesti pienituloisille kotitalouksille. (Oxley 2012; Ruonavaara 2017, 9; Czischke \& van Bortel 2018; Granath Hansson \& Lundgren 2018.) Kohtuuhintainen asuntotuotanto ei välttämättä tarkoita samaa kuin sosiaalinen, vaan sillä voidaan tarkoittaa alle markkinahintaista asuntokantaa, joka sijoittuu laveammin sääntelemättömän ja sosiaalisen asumisen välimaastoon, jolloin sen kohderyhmä on laajempi (czischke \& van Bortel 2018).

Se, mitä sosiaalisella tai kohtuuhintaisella asuntotuotannolla täsmälleen tarkoitetaan ja miten ne määritellään, vaihtelee maittain ja jopa kaupungeittain. Eroja on esimerkiksi asukasvalinnan kriteereissä, asuntotuotantoa koskevassa sääntelyssä, asumisen hintaan sisällytettävissä kuluissa, tai näkemyksissä missä määrin asumiskustannusten tulee alittaa markkinahinta. Joissain maissa asukasvalinnassa hyödynnetään myös kohtuullisten asumismenojen tulo-osuuksien laskentaa. (Hulchanski 1995; Czischke \& van Bortel 2018; Granath Hansson \& Lundgren 2018.)

Alle markkinahintaisen asuntokannan tuottaminen ja sen tukeminen on yleisesti käytetty asuntopoliittinen keino, jolla pyritään alentamaan asumisen hintaa. Asumisen kohtuuhintaisuuden osalta siinä on kuitenkin kaksi ongelmaa: edes alle markkinahintainen asumiskustannus ei ole automaattisesti kohtuullinen kotitalouksien maksukykyyn nähden, ja kohtuuhintaisuuden määrittely tällä tavalla rajaa kysymyksen ikään kuin vain tietyn hallintamuodon ominaisuudeksi (vrt. Stone 2006, 154; Haila 2015, 283).

\section{Aineisto ja analyysi}

Empiirisessä analyysissä tarkastelemme, miten asumisen kohtuuhintaisuus tulee määritellyksi Suomen asuntopolitiikassa ja millaisena kokonaisuutena se jäsentyy. Tutkimusmenetelmä on teoriaohjattu sisällönanalyysi, jossa sovellamme jakoa normatiiviseen, kuluttajavalintoihin perustuvaan ja asuntojen hallintasuhteisiin perustuvaan näkökulmaan.

Erilaiset politiikkaan ja julkiseen sektoriin kuuluvat toimijat ovat keskeisessä asemassa asumisen kohtuuhintaisuuden määrittelyssä. Tällaisiksi toimijoiksi olemme määritelleet valtioneuvoston, eduskunnan, ympäristöministeriön (YM), 
Asumisen rahoitus- ja kehittämiskeskuksen (ARA) sekä asumisen etuuksien osalta sosiaali- ja terveysministeriön (STM) ja Kansaneläkelaitoksen (KELA). Valtakunnallisen tason lisäksi tarkastelemme Helsingin, Tampereen ja Turun kaupunkien toteuttamaa asuntopolitiikkaa asumisen kohtuuhintaisuuden näkökulmasta. Kaupungistumisen vuoksi asumisen hinta on näissä kaupungeissa ajankohtainen yhteiskunnallinen kysymys. Suomessa kunnilla on myös verrattain paljon valtaa asuntopoliittisissa linjauksissa (Maankäyttö-ja rakennuslaki 132/1999; Kuntalaki 410/2015). Kaupunkien osalta keskeisiä toimijoita ovat kaupunkien asunto- ja maapolitiikan yksiköt sekä kaupunginvaltuustot, kaupunkien vuokrataloyhtiöt, ja maankäytön, asumisen ja liikenteen sopimusten (MAL) neuvottelukunnat.

Kirjallinen tutkimusaineistomme koostuu vuonna 2019 voimassa olleesta asumista koskevasta lainsäädännöstä ${ }^{4}$ sekä edellä mainittujen toimijoiden asuntopoliittisista ohjelmista, linjauksista, ohjeistuksista ja sopimuksista5. Hallitusohjelmia tarkastelimme aikavälillä 2007-2019. Tutkimusaineistoon sisältyy myös 17 asiantuntijahaastattelua ympäristöministeriöstä ja ARAsta sekä Helsingin, Turun ja Tampereen kaupunkien virkahenkilöistä, kaupunkeihin painottuen. Haastattelut tehtiin marraskuun 2018 ja toukokuun 2019 välisenä aikana. Aineiston analyysissä on käytetty NVIVO-ohjelmistoa.

\section{Tulokset}

Analyysimme jakautuu kolmeen osaan. Tarkastelemme ensin valtiotason asuntopolitiikan ohjelmallisia linjauksia hallitusohjelmissa, ympäristöministeriössä ja Asumisen rahoitus- ja kehittämiskeskuksessa. Analysoimme myös, mitä asuntopolitiikkaan kuuluu valtakunnallisella tasolla kohtuuhintaisuuden näkökulmasta. Analyysin toisessa osassa tarkastelemme ohjelmallisia linjauksia paikallisella tasolla Helsingissä, Tampereella ja Turussa. Kolmannessa osassa havainnollistamme kohtuuhintaisuuden ristiriitoja asuntopolitiikan toteuttamisessa. Käsittelemme neljää asuntopolitiikan kannalta olennaista kokonaisuutta: asuntotuotannon tukien ja MAL-sopimusten määritelmiä kohtuuhintaisuudesta, sosiaaliturvaan sisältyviä asumisen kohtuuhintaisuuden määritelmiä sekä vapaiden markkinoiden vuokra-asuntojen kohtuullisen vuokran määrittelyä.

4 Tutkimuksen kannalta keskeisiä lakeja ovat Laki yleisestä asumistuesta (938/2014), Laki eläkkeensaajan asumistuesta (571/2007), Laki Toimeentulotuesta (1412/1997), Laki asuinhuoneiston vuokrauksesta (481/1995) sekä arava- ja korkotukiasuntoja säätelevät lait (604/2001; 574/2016; 119o/1993; 1189/1993).

5 Aineisto kattaa hallitusohjelmat, hallitusten asuntopoliittiset ohjelmat, YM:n toimintaa ohjaavan strategian ja muut asiakirjat (kuten toiminnan seuranta-asiakirjat), ARAn strategian sekä ARAn julkaisemat oppaat vuokranmääritykseen, asukasvalintaan ja asuntorakentamiseen, KELA:n ohjeistukset toimeentulotuen ja asumistukien käsittelyyn, Helsingin, Tampereen ja Turun kaupunkiseutujen MAL-aiesopimukset sekä kyseisten kaupunkien asunto- ja maapoliittiset ohjelmat, kaupunkistrategiat sekä muut keskeiset dokumentit, kuten kaavoitusta ja asuntotuotantoa ohjaavat rakennemallit. 


\section{Valtion tason ohjelmalliset linjaukset}

Tarkastelimme, miten seitsemän viimeisen hallituksen ohjelmissa ja hallitusten asuntopoliittisissa ohjelmissa määritellään tai kuvataan asumisen kohtuuhintaisuutta. Näissä ohjelmissa on tehty asuntopoliittiset tavoitteet ja linjaukset kunkin hallituskauden ajaksi. Yhdessäkään asumisen kohtuuhintaisuutta ei määritellä yksiselitteisesti ja eri näkökulmat sekoittuvat. Ohjelmien yleisissä tavoitteissa esitetään normatiiviseen näkökulmaan viittaavia määreitä kohtuullisista asumiskustannuksista suhteessa tuloihin. Vanhasen hallituksen asuntopoliittisessa ohjelmassa tavoitteena on "edistää asumisen kohtuuhintaisuuden toteutumista" (Yм 2008, 5). Kataisen hallituksen asuntopoliittisessa ohjelmassa "edistetään kohtuuhintaista asumista" ja keskitytään toimiin, joilla voidaan "kohtuullistaa asumismenoja" (valtioneuvosto 2012, 1-2). Rinteen ja Marinin hallitusohjelmien mukaan "ihmiset kärsivät asumisen kalleudesta, sillä monilla asuminen vie tuloista liian suuren osan" (valtioneuvosto 2019a, 46; 2019b, 48). Näille tavoitteille ei esitetä konkretiaa, kuten asiaan liittyvää standardia tai mittaria, mitä asumisen kohtuuhintaisuudella tarkoitetaan. (Artikkelia viimeisteltäessä Marinin hallituksen asuntopoliittinen ohjelma oli vasta valmisteilla.)

Asuntomarkkinoiden toimivuutta korostavat tavoitteet viittaavat kuluttajavalintoja painottavaan näkökulmaan. Kataisen hallitusohjelmassa tavoitteena on "sosiaalisesti ja alueellisesti tasapainoiset ja vakaat asuntomarkkinat" (Valtioneuvosto 2011, 72) ja Vanhasen ohjelmassa tehdään toimia "asuntomarkkinoiden vakauttamiseksi" (Valtioneuvosto 2007, 64). Sipilän (Valtioneuvosto 2015) ja Stubbin (Valtioneuvosto 2014) hallitusohjelmat lähestyvät asumista selkeimmin kuluttajavalintojen ja markkinaehtoisen määrittelyn näkökulmasta; asumisen kohtuuhintaisuutta ei mainita terminä, vaan asuntopoliittiset tavoitteet keskittyvät asuntotarjonnan lisäämiseen ja kysyntään vastaamiseen - että kuluttajille olisi mistä valita. Toisaalta ohjelmat rinnastavat kohtuuhintaisuuden toistuvasti alle markkinahintaiseen asuntokantaan, jota nimitetään usein juuri kohtuuhintaiseksi. Esimerkiksi Kataisen ohjelmassa pyritään lisäämään "pieni- ja keskituloisille tarkoitettujen kohtuuhintaisten asuntojen tuotantoa" (valtioneuvosto 2011, 72). Retoriikassa on eroja, mutta jokainen hallitus on pyrkinyt edistämään asumisen kohtuuhintaisuutta ensisijaisesti asuntotuotantoa koskevilla tavoitteilla ja mittareilla.

Ympäristöministeriö (YM) vastaa Suomessa asuntopolitiikkaan liittyvien asioiden valmistelusta valtioneuvostolle ja eduskunnalle. YM:n asiakirjoissa asumisen kohtuuhintaisuuden ongelmallisuus esitetään niin, että asuminen on liian kallista tuloihin nähden, mutta asiaa ei määritellä tämän yksityiskohtaisemmin. YM:n strategiassa asuntopolitiikan tavoitteiksi asetetaan, että "asuntoja on eri väestöryhmien tarpeisiin kysyntää vastaavasti" (צM 2018a), ja 
tavoiteltavana tulevaisuutena kuvataan tilanne, jossa "asumisen hinta on kohtuullinen" (Valtioneuvosto 2018, 11). Asuntotarpeisiin vastaamisen tavoitetta seurataan indikaattorilla, joka kuvaa asumismenojen osuutta tuloista (YM 2018a). Tämä viittaa normatiiviseen näkökulmaan, mutta strategiassa osuudelle ei kuitenkaan esitetä standardiarvoa, jota asumismenot eivät saisi ylittää. Pääpainopiste on kuluttajavalinnoissa ja alle markkinahintaisen asuntokannan näkökulmissa, joita muut toimet tukevat. Asumisen tuet ja riittävä asuntotarjonta sekä tarjonnan vastaaminen kysyntään erotetaan keskeisinä asuntopoliittisina keinoina päästä kohtuuhintaisuuden tavoitteeseen: "Riittävä asuntotarjonta ja valtion suunnatut tukitoimet mahdollistavat kohtuuhintaisen asumisen." (Yм 2018b; myös YM 2019a; YM 2019b). YM:ssä asuntopolitiikan seuranta kohdistuu sekä koko asuntotuotannon että alle markkinahintaisen asuntokannan määriin, joista jälkimmäiseen viitataan myös termillä “kohtuuhintainen” (YM 2019c, 37-38).

Ympäristöministeriön alaisuudessa toimiva Asumisen rahoitus- ja kehittämiskeskus (ARA) on keskeinen valtion asuntopolitiikan toimeenpanija, joka muun muassa myöntää asuntotuotannon avustuksia ja valvoo valtion tuella rakennetun asuntokannan käyttöä. ARAn tavoite on edistää "kestävää ja kohtuuhintaista asumista" (ARA 2016). Sen tulostavoitteena kuvataan, että "tuloihin nähden kohtuuhintainen asuntotarjonta kasvukeskuksissa lisääntyy pieni- ja keskituloisille kotitalouksille" (ARA 2019b). Seurantaan valitut indikaattorit kuitenkin kuvaavat vain alle markkinahintaisten, valtion tuella rakennettujen vuokraasuntojen tuotantoa, vuokratasoa ( $€$ /neliö/kuukausi) ja rakennuskustannuksia (emt.). Tuloihin suhteutuvaa asumismenojen kohtuullisuuden mittaria ei esitetä. Kohtuuhintaisuus rinnastuu täten alle markkinahintaiseen asuntokantaan ja määrittyy asuntojen hallintamuotojen näkökulmasta. Myös ARAn muissa asiakirjoissa kohtuuhintaisuutta lähestytään asuntojen hallintamuotoina, jossa valtion korkotuki asuntotuotantoon on "keskeisin kohtuuhintaisen vuokra-asuntotuotannon tukimuoto", mutta pohditaan, että kohtuuhintaiseen asuntotuotantoon tulisi lukea laajemmin erilaisia tuotantomuotoja kuin vain vuokra-asunnot (ARA 2019c).

Valtion tason ohjelmallisissa linjauksissa keskeiseksi määritelmäksi kohtuuhintaisuudelle muodostuu alle markkinahintainen asuntokanta, joka kohdennetaan sosiaalisin perustein eniten tarpeessa olevalle väestönosalle. Muutoin sovelletaan kuluttajavalintojen näkökulmaa, jossa markkinat määrittelevät kohtuuhintaisuuden. Tämä ilmenee yhtäällä epäsuorasti tavoitteissa pyrkiä asuntomarkkinoiden tasapainoon ja toisaalla normatiivisten määritelmien puutteena.

Kokonaisuuden kannalta ongelma on, että YM:n ja ARAn mandaatti rajoittuu asuntotuotantoon ja asumistasoon liittyvien tekijöiden valmisteluun 
ja seurantaan. Vaikka asumisen kalleutta suhteessa kotitalouksien tuloihin ja asuntopolitiikan kokonaisuutta pohditaan esimerkiksi YM:n strategiassa, selkeät kannanotot tai normatiiviset standardit tulojen ja asumismenojen suhteesta rajautuvat hallinnonalan ulkopuolelle. Näin päästään jopa näkemykseen, jossa tuloihin tai asumismenojen osuuteen liittyvät ongelmat eivät ole asuntopolitiikalla ratkaistavia kysymyksiä:

Asuntopolitiikalla ei voi ratkaista muita ongelmia mitä yhteiskunnassa syntyy eli jos tämmöinen eriarvoisuus kasvaa ja pienituloisten tulot ei kasva -.. (haastattelu 9)

Tulojen ja asumismenojen osalta kokonaisuus hajautuu valtionhallinnossa useiden ministeriöiden vastuulle. Näistä keskeisin on sosiaali- ja terveysministeriö (STM), jonka alaan kuuluvat toimeentuloon ja sosiaaliturvaan liittyvät asiat, mukaan lukien asumistuet vuodesta 2008 alkaen. Tulojen osalta kytköksiä asuntopolitiikkaan käsitellään harvakseltaan. Esimerkiksi hallitusohjelmissa toimeentuloa käsitellään pääosin osana sosiaaliturvaa tai työllisyyspolitiikkaa. Poikkeuksen muodostavat Rinteen ja Marinin hallitusohjelmat, joissa asumisen kohtuuhintaisuus mainitaan myös asumistuen yhteydessä.

On selvää, että asumisen kysyntätuet, keskeisimpänä yleinen asumistuki, ovat yhtä lailla valtion asuntopolitiikkaa kuin tuotantotuetkin. Ne ovat tukea asumisen omatoimiseen järjestämiseen sen suurimmassa tarpeessa oleville. Nykyisellään kokonaisuuden hallinta jättää kuitenkin toivomisen varaa, vaikka valtiolla on merkittävä rooli sekä sosiaaliturvan raamien että asuntotuotannon tavoitteiden ja asuntokannan kehittämisen ohjauksessa. Ongelma ei ole täysin hahmottamatta, vaan samantapainen huoli asuntopolitiikan kokonaisotteen puuttumisesta ja irrallisuudesta muusta yhteiskuntapolitiikasta ilmenee esimerkiksi eduskunnan tarkastusvaliokunnan asuntopolitiikan kehittämistä koskevasta mietinnöstä:

Valiokunta painottaa asuntopolitiikan laajaa yhteiskunnallista merkitystä ja pitää huolestuttavana valiokunnan tilaamassa tutkimuksessa ja asiantuntijakuulemisessa esitettyjä arvioita, joiden mukaan asuntopolitiikan yhteiskunnallista merkitystä on aliarvioitu. (Tarkastusvaliokunta 2018, 37).

\section{Kaupunkien ohjelmalliset linjaukset}

Helsingin, Tampereen ja Turun kaupunkien asuntopolitiikassa asumisen kohtuuhintaisuutta lähestytään monipuolisesti, erilaisia näkökulmia yhdistellen. Sekä asuntopoliittisissa linjauksissa että asiantuntijahaastatteluissa viitattiin normatiiviseen näkökulmaan, jonka mukaan asumisen ei tulisi maksaa liikaa 
suhteessa kotitalouksien tuloihin. Asuntopolitiikan tavoitteeksi ilmaistiin esimerkiksi "turvata tavallisten helsinkiläisten asumisen mahdollisuudet, ja kaupungin tulee omilla toimillaan edistää kohtuuhintaista asumista" (Helsingin kaupunki 2016,17) tai että asuntopolitiikka tarkoittaa toimenpiteitä, joilla varmistetaan "asumisen kohtuuhintaisuus" (Tampereen kaupunki 2018,1). Useissa asiantuntijahaastatteluissa pohdittiin asumisen kalleutta tai kuvailtiin asumisen kohtuuhintaisuutta suhteena kotitalouden tulojen ja menojen välillä sekä erilaisina käsityksinä siitä, että elämiseen jäisi riittävästi rahaa tai olisi mahdollisuuksia hankkia tarpeita vastaava asunto.

Kohtuuhintainen asuminen on asumista, missä ihmiset voivat asua tarpeitansa tyydyttävällä tavalla, mutta käyttämättä siihen kohtuuttoman suurta osaa tuloistansa. (haastattelu 14)

Haastattelujen perusteella asumisen kohtuuhintaisuutta ja sen määritelmiä pohditaan osana asuntopolitiikan valmistelua, mutta käsitteen tarkka määrittely tai mittaaminen nähdään vaikeana. Osa haastateltavista mainitsi, että esimerkiksi tulo- ja meno-osuudet olisivat yksi keino mitata kohtuuhintaisuutta. Käsitteen hankaluus tiivistyy hyvin Helsingin kaupungin asunto-ohjelmassa, jossa kysymystä lähestytään yleisellä tasolla normatiivisesta näkökulmasta ja pohditaan myös kohtuuhintaisuuden kokonaisuutta, mutta konkretisoiminen jätetään kuitenkin avoimeksi ja itse asia lopulta kunkin kotitalouden omaksi valinnaksi.

Asumisen kohtuuhintaisuutta on vaikea määritellä yksiselitteisesti, koska asuinneliöiden lisäksi maksetaan myös sijainnista, saavutettavuudesta, laadusta ja kunnosta, asuinympäristöstä sekä asuinalueen statuksesta. Kohtuuhintaisuus määrittyy lisäksi aina suhteessa käytettävissä oleviin tuloihin ja varallisuuteen, ja tarkoittaa siten eri asiaa eri asukasryhmille.

(Helsingin kaupunki 2016, 30)

Mitattavaksi standardiksi asumisen kohtuuhintaisuus konkretisoituu vain sosiaaliturvassa määriteltyjen, kuntakohtaisten enimmäisasumismenojen muodossa (ks. seuraava luku). Kaupunkien omassa politiikassa normatiivinen näkökulma tulojen ja menojen sopivasta suhteesta jää täsmentämättä. Tulotasoa, etuuksien käyttöä ja työllisyystilannetta seurataan asunto-ohjelmien taustoituksessa, ja asumisen hintaa neliöhintoina tai keskivuokrina. Erityyppisten kotitalouksien tuloja ja asumisen menoja ei kuitenkaan tarkastella suhteessa toisiinsa.

Myös kaupunkien määrällisissä tavoitteissa asumisen kohtuuhintaisuus rinnastuu usein alle markkinahintaiseen asuntokantaan. Kaupungit määrittelevät 
selvästi, mitä tähän kantaan kuuluu ja mitkä ovat sille asetetut tuotantotavoitteet. Tarkat määritelmät vaihtelevat kaupunkien välillä, mutta kohtuuhintaisuus rinnastuu etenkin valtion korkotuella rakennettuihin sosiaalisiin vuokraasuntoihin eli ns. ARA-vuokra-asuntoihin. Lähes kaikki haastattelemamme asiantuntijat tunnistivat tämän näkökulman kohtuuhintaisuuden määrittelyyn, joskin osa heistä piti sitä turhan yksinkertaistavana.

Perinteisesti Suomessa [kun] monet puhuu kohtuuhintaisesta asumisesta, niin [ne] puhuu pitkästä korkotuesta tai Ara-vuokrista. Mut se ei musta ihan oo niin yksinkertainen. (haastattelu 15)

Esimerkiksi Tampereen asunto- ja maapoliittisessa ohjelmassa (Tampereen kaupunki 2018, 18), kohtuuhintainen asuminen määritellään laajasti erilaisina alle markkinahintaisen asuntokannan muotoina.

Kohtuuhintainen asuminen on keskeinen kaupungin kilpailutekijä. Sillä pyritään mahdollistamaan kaikille kaupunkilaisille tarkoituksenmukainen asunto. Kohtuuhintaisella asumisella tarkoitetaan ARAn pitkällä 40-vuotisella korkotuella ja lyhyellä korkotuella toteutettuja vuokra-asuntoja, asumisoikeusasuntoja, kaupunkikonserniin kuuluvien vuokra-asuntoyhteisöjen toteuttamia vuokra-asuntoja sekä kohtuuhintaisia omistusasuntoja. Mahdollisesti käyttöönotettavalla osuuskunta-asumisen mallilla olisi myös mahdollista tuottaa kohtuuhintaista asumista. (Tampereen kaupunki 2018, 18)

Asuntotarjonnan lisäämistä painottavat tavoitteet viittaavat kuluttajavalintojen näkökulmaan, jossa asuntokysymys ratkaistaan ensisijaisesti markkinoilla. Kaikissa kolmessa kaupungissa tärkein asuntopoliittinen keino edistää asumisen kohtuuhintaisuutta on lisätä asuntotuotantoa ja tukea siten asuntomarkkinoiden toimintaa. Siihen ei sisälly normatiivista kantaa kustannuksista. Kaupungit esittävät asuntotuotannon lisäämiselle selkeitä, mitattavia tavoitteita, joita seurataan toteutuneiden tuotantomäärien, tontinluovutusten ja hallintamuotojen osuuksilla.

\section{Asumisen kohtuuhintaisuuden tulkinnat asuntopolitiikan toteutuksessa}

Asumisen kohtuuhintaisuutta koskevat periaatteelliset pulmat tulevat esiin, kun tarkastellaan asuntopolitiikan toteuttamista käytännössä. Esitämme lainsäädännön, ohjelmien ja asiantuntijahaastatteluiden perusteella neljä oleellista esimerkkiä koskien alle markkinahintaista asuntokantaa, MAL-aiesopimuksia, sosiaaliturvan enimmäisasumismenoja ja vapaiden markkinoiden vuokra-asuntoja. 


\section{Asuntotuotannon tuet ja alle markkinahintainen asuntokanta}

Asuntotuotannon tuet ovat Suomessa merkittävä asuntopoliittinen työkalu lisätä alle markkinahintaisten asuntojen tarjontaa. Toimenpiteet kohdistuvat etenkin vuokra-asumiseen, mutta tähän asuntokantaan kuuluu Suomessa myös asumisoikeusasuntoja ja omistusasuntoja. Valtion tuella rakennetaan erityisesti vuokra-asuntoja, joiden tulee olla asumiskustannuksiltaan kohtuullisia ja joihin valitaan asukkaat sosiaalisin perustein (Laki vuokra-asuntolainojen ja asumisoikeustalolainojen korkotuesta 604/2001 4 § \& 11 a §; Laki vuokratalojen rakentamislainojen lyhytaikaisesta korkotuesta 574/2016 2 § 4 §; Aravalaki 1189/1993 5 §). Valtion tuella rakennettujen asuntojen asumiskustannukset ovat sääntelyn piirissä ja niiden muodostamista koskevat periaatteet ja rajoitusajat kuvataan laeissa, asetuksissa ja ohjeistuksissa (ks. tarkemmin ARA 2018). Tuilla rakennettuihin vuokra-asuntoihin viitataan muun muassa termeillä ARA-vuokra-asunto, sosiaalinen vuokra-asunto, pitkän korkotuen vuokra-asunto tai valtion tukema kohtuuhintainen vuokra-asunto. Koko kantaan viitataan usein kohtuuhintaisena, mutta myös tuettuna tai säädeltynä.

Alle markkinahintaisessa asuntokannassa asumiskustannusten kohtuullisuus määrittyy omakustannusperiaatteella ja pyrkimyksenä alle markkinahintaiseen asumiskustannukseen. Omakustannusperiaate tarkoittaa, että asumisesta peritään vain se hinta, joka tarvitaan asunnon (tai laveammin omistajan hallinnoiman asuntokannan) tuottamiseen ja ylläpitämiseen. Vuokrat pyritään pitämään kohtuullisina myös edistämällä lainojen pääomamenojen ennakoitavuutta. (ARA 2018; 604/2001 13 §; HE 181/200O vp, 7; 119O/19937 §.) Niin sanotussa lyhyessä korkotuessa ARA vahvistaa tukikohteille sitovan alkuvuokran, jonka määrittely muistuttaa omakustannusperiaatetta (574/2016 13 §; ARA 2019a, 7). Tuotantotuissa on siis normatiivisia elementtejä, sillä omakustannusperiaatteen noudattaminen tarkoittaa muun muassa voiton kerryttämisen rajaamista. Tämä ei kuitenkaan vastaa tässä tutkimuksessa tarkoitettua normatiivista näkökulmaa, jossa kiinnostus on asumiskustannusten vertaamisessa yksittäisten kotitalouksien maksukykyyn. Alle markkinahintaisessa asuntokannassa normatiivisuus liittyy asuntokantaa koskeviin rajoituksiin sekä asuntojen kohdentamiseen. Kohtuuhintaisuus rinnastuu siten asuntojen hallintamuotoihin.

Alle markkinahintaista asuntokantaa nimitetään sekä dokumentti- että haastatteluaineistossa toistuvasti kohtuuhintaiseksi. Tämä voi luoda mielikuvan, että asumismenojen kohtuullisuutta arvioitaisiin suhteessa yksittäisten kotitalouksien tuloihin normatiivisen näkökulman mukaisesti (vrt. Stone 2006, 154). Tällaista vertailua ei kuitenkaan tehdä. Siksi asuntokannan nimittäminen kohtuuhintaiseksi voi olla harhaanjohtavaa; omakustannusperiaate tai alle markkinahintaisuus eivät vielä takaa, että asumismenot tällaisessa asunnossa olisivat kohtuuhintaisia kotitalouden tuloihin nähden. Selvintä olisi nimittää 
kantaa täsmällisellä termillä, kuten tässä artikkelissa käytetty alle markkinahintainen asuntokanta.

\section{Maankäytön, asumisen ja liikenteen (MAL) -aiesopimukset}

Maankäytön, asumisen ja liikenteen (MAL) -aiesopimukset ovat valtion tason asuntopoliittinen keino sekä keskeinen suurimpien kaupunkiseutujen liikenneja asuntopolitiikan tavoitteita kehystävä asiakirja. Sopimukset pohjautuvat valtion ja kaupunkiseutujen välisiin neuvotteluihin ja niissä määritellään tavoitteet asuntotuotannon kokonaismäärälle sekä alle markkinahintaisten asuntojen osuudelle. Tavoitteet ovat kuntakohtaisia ja niiden täyttymistä seurataan säännöllisesti. Tarkastelimme tässä analyysissä Helsingin, Tampereen ja Turun kaupunkiseutujen vuosien 2016-2019 MAL-sopimuksia.

Asumisen kohtuuhintaisuuteen viitataan sopimuksissa epäsuorasti asuntotuotannon kokonaismääriä kuvaavissa tavoitteissa, kuten esimerkiksi Helsingin seudun tavoite "asuntotuotantotarpeeseen vastaaminen" (YM 2016a, 3). Nämä viittaavat kuluttajavalintojen näkökulmaan, jossa pyritään asuntomarkkinoiden tasapainoon tuottamalla lisää asuntoja.

Selvimmin kohtuuhintaisuus määrittyy MAL-sopimuksissa alle markkinahintaisena asuntokantana eli käsitettä lähestytään asuntojen hallintamuotojen näkökulmasta. Kohtuuhintaisuus mainitaan eksplisiittisesti vain alle markkinahintaista asuntokantaa koskevissa tavoitteissa. Tampereen kaupunkiseudulla tätä kantaa kuvataan "asumiskustannuksiltaan kohtuuhintaisena vuokra-asuntotuotantona" (Tampereen kaupunkiseutu 2016, 10), Turun seudulla "valtion tukemana kohtuuhintaisena asuntotuotantona" (YM 2016b, 9) ja Helsingin seudulla "tuettuna asuntotuotantona" (YM 2016b, liite 1). Sopimuksissa on seutukohtaisia eroja, mitä kantaan luetaan kuuluvaksi.

MAL-sopimusten määritelmä kohtuuhintaisuudesta aiheuttaa tulkintavaikeuksia asuntopolitiikan toimijoiden välillä. Haastatteluissa kävi selvästi ilmi, että kaupunkitasolla kohtuuhintaisuus ymmärretään laveammin kuin mitä sopimuksiin on kirjattu.

[MAL-sopimuksissa] tuntuis olevan ARA-rahoitukset kauhean merkittävässä roolissa. Kun sitten kuntien kanssa keskustellaan, niin he näkee sen toisin. [Kunnille] kohtuuhintainen asuminen on kohtuuhintaista asumista. Eli sillon Ara-rahoitus ei oo niin suuressa roolissa kuin se varsinainen vuokran hinta asukkaalle. (haastattelu 7)

Yksi nykyisistä ongelmista on tässä: MAL-sopimusten kontekstissa asumisen kohtuuhintaisuuden tavoite on täytetty, kun juuri sopimuksen kirjauksen mukainen alle markkinahintaisen, yleensä ARA-korkotukilainoitetun asunto- 
tuotannon tavoite on saavutettu. Vastaavasti tulkinta voi mustavalkoisesti olla, ettei tavoite täyty, jos tuotanto ei ole juuri sopimuksen mukaista, asumisen hinnasta riippumatta. Tämä aiheuttaa kitkaa ja on hyvä esimerkki siitä, miten kohtuuhintaisuutta tulkitaan julkisen sektorin toimijoiden välillä ristiriitaisesti.

[ARA-tuotantoa ja sitä vastaavaa tuotantoa] tässä seurataan. Mut sitten kunnista sai vastauksen, että meillä on kohtuuhintaista asumista, mutta se ei oo ARAa, jolloin [MAL-sopimusten seurannassa] ajatellaan, että heillä ei oo kohtuuhintaista asumista. (haastattelu 7)

\section{Asumiseen liittyvät etuudet}

Asumisen kohtuuhintaisuuteen otetaan kantaa asumiseen liittyvissä etuuksissa. Asumisen kannalta keskeisimmät etuudet ovat yleinen asumistuki (938/2014), eläkkeensaajan asumistuki (571/2007) ja toimeentulotuki (1412/1997). Asumistuilla tuetaan hakijan toimeentuloa ja tavoitteena on, että asumismenojen maksamisen jälkeen tuloja jäisi riittävästi muiden menojen kattamiseen. (938/2014, 1 §,

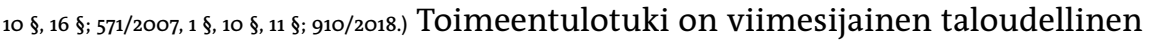
tuki, jonka tavoitteena on turvata hakijan toimeentulo ja edistää itsenäistä selviytymistä (1412/1997,1 §).

Asumistuissa kohtuuhintaisuus määritellään kuntakohtaisissa enimmäisasumismenoissa. Ne vaikuttavat tuen suuruuteen ja ne määritellään laissa tai asetuksissa. Asumistuissa määritellään myös omavastuuosuus, joten tuki ei kata

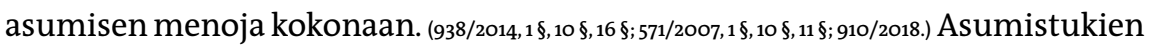
ja toimeentulotuen kohtuullisiksi määritellyt asumismenot pohjaavat muun muassa kuntien vuokrien keskihintatasoon (HE 90/2006 vp., 13; HE 52/2014 vp, 9; Kela 2018).

Toimeentulotukea koskevassa laissa asumismenoille ei määritellä enimmäismäärää eikä omavastuuosuutta. Toimeentulotuessa asumismenot huomioidaan lähtökohtaisesti "todellisen suuruisina, jollei niitä ole pidettävä kohtuuttomina" (HE 217/1997 vp, 20). Tavoitteena on asumisen turvaaminen. Kohtuulliset enimmäisasumismenot määritellään kuitenkin kuntakohtaisesti Kelan ohjeistuksissa (Kela 2020). Ne perustuvat vuokrarajoihin, jotka kunnat määrittelivät ennen toimeentulotuen siirtämistä Kelaan, ja joita on tarkistettu Kelassa tarpeen mukaan (Kela 2018). Jos toimeentulotuen hakijan asumismenot ylittävät kohtuullisiksi katsotun määrän, kehotetaan hakijaa hakeutumaan edullisempaan asuntoon. Tässä voidaan kuitenkin joustaa, jos asumisen turvaaminen edellyttää sitä. (1412/1997, 7 b §.)

Asumiseen liittyvät etuudet ovat selkein normatiivinen määritelmä asumisen kohtuuhintaisuudelle Suomessa. Ne asettavat euromääräisen rajan, mitä sosiaaliturvan näkökulmasta pidetään kussakin kunnassa kohtuullisena asumismenona. Kotitalouksien näkökulmasta ne asettavat ylärajan, paljonko 
asumiseen voi saada tukea. Etuudet päätyvät kuitenkin keskenään erilaisiin kohtuullisten asumismenojen määritelmiin. Raja on alhaisin yleisessä asumistuessa, kun taas toimeentulotuessa hyväksytään selkeästi korkeammat asumismenot (ks. myös Saikkonen ym. 2018, 106).

Nykyisellään enimmäisasumismenot eivät vastaa suurimpien kaupunkien asumiskustannusten tasoa. Esimerkiksi kohtuullisen minimin kulutusta mittaavat viitebudjetit arvioivat asumiskustannukset monissa kuntatyypeissä selvästi toimeentulotuen rajojakin korkeammiksi (ks. Lehtinen \& Aalto 2018, 66). Helsingissä, Tampereella ja Turussa on arvioitu asumiskustannukset jo niin korkeiksi, että pienituloisten kotitalouksien kohdalla asumistuki ei riitä asumismenojen kattamiseen vaan lisäksi tarvitaan usein toimeentulotukea (saikkonen ym. 2018).

Etuuksien tason riittävyys tuli esille myös haastatteluaineistossa. Etuuksien enimmäisasumismenoja sovelletaan jossain määrin alle markkinahintaisen asuntokannan vuokrien määrittelyssä. Haastattelujemme perusteella kaupunkien vuokrataloyhtiöt pyrkivät omakustannusperiaatteen lisäksi huomioimaan vuokrissa paikalliset toimeentulotuen ja yleisen asumistuen enimmäisasumismenot sekä seuraavat niitä tarkasti. Tätä perusteltiin sillä, että vuokrataloyhtiöiden asiakaskunta on pääsääntöisesti pienituloista ja vuokrien suuruus pyritään sovittamaan asiakaskunnan rahkeisiin. Eräs haastateltava täsmensi, että erityisryhmille suunnatussa asuntotuotannossa vuokria voidaan sovittaa esimerkiksi eläkkeensaajan asumistuen rajoihin. Toisaalta haastateltavat toivat esille, että valtion taholta asetetut enimmäisasumismenot eivät aina ole riittävät kaupunkien vuokratasoon verrattuna. Asian voi nähdä niinkin, että kyse on valtion asumiseen käyttämän tuen, ei asumismenojen saati kohtuuhintaisuuden määrittämisestä. Sosiaaliturvassa määritellyistä kohtuullisuuden rajoista aiheutuu näin neuvonpitoa valtion ja kaupunkien välillä.

\section{Vapaiden markkinoiden vuokra-asunnot}

Suomessa yhä useampi kotitalous asuu vuokralla ja vuokra-asuminen yleistyy suhteellisesti eniten vapailta markkinoilta vuokratuissa asunnoissa (svT 2019). Näissä vuokra-asunnoissa vuokran suuruus määräytyy vuokranantajan ja vuokralaisen välisenä sopimuksena (Laki asuinhuoneiston vuokrauksesta 481/1995, 27 §). Vuokran enimmäismäärää ei ole säädelty sen jälkeen kun vuokrasäännöstely purettiin 1990-luvun alkupuolella (Kettunen \& Ruonavaara 2015). Vuokrasuhteen osapuolilla on kuitenkin lain mukaan oikeus selvittää vuokran kohtuullisuus (481/1995 29 \& 30 §), jolloin sitä verrataan muiden markkinoilla olevien vuokra-asuntojen hintatasoon. Keskeinen vuokran kohtuullisuuden arviointiin vaikuttava tekijä on "miten huoneiston eri ominaisuuksia kulloinkin arvostetaan". Ominaisuuksia ovat esimerkiksi koko, sijainti, kunto ja varustetaso. (HE 304/1994 vp, 12.) Vuokran 
kohtuullisuus määräytyy siis kuluttajavalintoja painottavan näkökulman mukaisesti ja markkinaehtoisesti.

Yksityinen vuokra-asuminen liittyy asumisen kohtuuhintaisuuden kokonaisuuteen läheisesti siten, että kotitaloudet voivat parantaa valinnanmahdollisuuksiaan ja maksukykyään markkinoilla hakemalla asumistukea. Tosin, kuten edellä todettiin, tukien taso ei vastaa kaikilta osin suurimpien kaupunkien vuokratasoa. Asumistukimenot ovat kasvaneet selvästi vuoden 2008 finanssikriisin jälkeen, ja tukien saajat ovat suurelta osin vuokra-asukkaita. Lisäksi entistä useampi työssäkäyvä saa asumistukia. Kehityksen on arveltu johtuvan osaksi matalapalkkatyön yleistymisestä sekä asuntojen vuokrien noususta etenkin pääkaupunkiseudulla ja osaksi tukijärjestelmän muutoksista, muun muassa opiskelijoiden siirtämisestä yleisen asumistuen piiriin. (Huhtala, Kekäläinen \& Noro 2017; Matala 2018; Kela 2019.)

\section{Johtopäätökset}

Tarkastelimme artikkelissa, miten asumisen kohtuuhintaisuutta on viime vuosina määritelty Suomen asuntopolitiikassa. Analyyttisessä viitekehyksessä erotimme normatiivisen, kuluttajavalintoja painottavan ja asuntojen hallintamuotoihin perustuvan näkökulman.

Normatiivinen näkökulma, jonka mukaan asuminen ei saisi maksaa liikaa suhteessa kotitalouksien tuloihin, esiintyy usein politiikkadokumenttien johdannoissa. Myös suurin osa haastatelluista asiantuntijoista käsitti kohtuuhintaisuuden tulojen ja asumismenojen suhteena. Varsinaisissa asuntopolitiikka linjaavissa päätöksissä näkökulma jää kuitenkin viitteelliseksi ja vaille konkretiaa. Asumisen kohtuuhintaisuutta ei Suomessa seurata systemaattisesti normatiivisesta näkökulmasta eikä siitä ole asuntopolitiikan toimijoiden jakamaa yhteistä näkemystä. Kuitenkin asumista koskevat etuudet ovat näkökulman mukainen ja vaikutuksiltaan merkittävä käytännön sovellus.

Poliittisissa ohjelmissa asuntopolitiikaksi asumisen kohtuuhintaisuus määrittyy ennen kaikkea kuluttajavalintojen näkökulmasta ja asuntojen hallintamuotoihin perustuen. Valtakunnallisella tasolla kokonaisuutta hallinnoi ympäristöministeriö ja kaupungeissa siitä vastaavat etenkin asunto- ja maapolitiikan yksiköt.

Kuluttajavalintoja painottava näkökulma ilmentää Suomen asuntopolitiikan lähtökohtia: asuntokysymys ratkaistaan ensisijaisesti markkinoilla (Juntto 199o, Ruonavaara 2013). Asuntopolitiikan tärkein tavoite on riittävä asuntotuotanto ja asuntojen tarjonta, tällä hetkellä etenkin suurissa kaupungeissa ja niiden kaupunkiseuduilla. Tästä näkökulmasta myös asumisen kohtuuhintaisuus määritellään viime kädessä markkinoilla. Kuluttajavalintojen näkökulma ei 
kuitenkaan yksinään riitä selventämään, miten asuntopolitiikan keskeiset tavoitteet asumistarpeiden täyttymisestä toteutuvat eri väestöryhmien kohdalla ja millaista eriarvoisuutta asumiseen liittyy.

Ongelmallista on myös kohtuuhintaisuuden toistuva rinnastaminen alle markkinahintaiseen asuntokantaan. Erityisen sitkeässä istuu sen samastus ARA-tuotantoon eli valtion tuotantotuilla rakennettuihin sosiaalisiin vuokraasuntoihin. Tälle asuntokannalle esitetään selviä tuotantotavoitteita, joiden toteutumista seurataan aktiivisesti ja yksioikoisesti. Hallintamuotoihin tukeutuvalla määrittelytavalla ei kuitenkaan päästä kiinni siihen, onko asuminen kohtuuhintaista kotitalouksien tuloihin nähden välttämättä edes tuossa kannassa tai - mikä merkittävämpää - yleisemmin. Rinnastaminen sosiaalisiin vuokraasuntoihin on ongelmallista, koska se antaa ymmärtää, että koko kohtuuhintaisuuden käsite liittyy vain marginaaliryhmiin ja osaksi sosiaalipolitiikkaa (vrt. Haila 2015, 283). Asumisen kalleus koskettaa kuitenkin laajasti pieni- ja keskituloisia kotitalouksia, ja kytkeytyy tuloeroihin ja eriarvoisuuteen kaupungeissa. Asiaan on kiinnitetty huomiota myös asuntopolitiikkaa käsittelevissä mietinnöissä (esim. Tarkastusvaliokunta 2018), mutta toimenpiteet antavat odottaa itseään.

Kuluttajavalintojen näkökulman painottuminen asuntopolitiikassa kytkee kohtuuhintaisuuden kysymyksen vahvasti normatiiviseen näkökulmaan pohjautuviin kysyntätukiin eli asumisen etuuksiin. Niillä parannetaan kuluttajien valinnanmahdollisuuksia asuntomarkkinoilla. Näistä keskeisimpiä ovat asumistuet, mutta etenkin suurimmilla kaupunkiseuduilla asumisen hinta edellyttää usein myös turvautumista toimeentulotukeen (esim. Saikkonen ym. 2018). Suomessa asumistukia käyttävät valtaosin vuokralaiset (Matala 2018) ja juuri vuokra-asukkaat nostetaan usein esille ryhmänä, jolle asumiskustannukset ovat rasittavimmat suhteessa tulotasoon (esim. Ilmarinen \& Kauppinen 2018; FEANTSA \& The Fondation Abbé Pierre 2019). Nykyisellään tukien taso ei vastaa kaikilta osin suurimpien kaupunkiseutujen vuokrien tasoa.

Asumisen kohtuuhintaisuuden edistämisen kannalta keskeisten asuntopolitiikan työkalujen - kysyntä- ja tarjontatukien - jakautuminen kahden ministeriön (YM ja STM) alaisuuteen ilman kokonaisvaltaista poliittista ohjausta on erikoista. Nykyisellään Suomen asuntopolitiikka on asumisen kohtuuhintaisuuden näkökulmasta hajautunutta ja kokonaisuuden hallinta retuperällä. Tämä heijastuu myös yhtenäisen ja toimijoiden jakaman käsitteen määritelmän puutteena ja vaihtelevana termistönä, mitkä vaikeuttavat kokonaisuuden hahmottamista. Jaetun näkemyksen puute näkyy muun muassa toimijoiden välillä ristiriitaisina käsityksinä siitä, miten kohtuuhintaisuutta edistetään tarkoituksenmukaisesti MAL-sopimusten puitteissa tai mikä olisi asumistukien oikea taso suhteessa vuokriin suurissa kaupungeissa. 
Kaiken kaikkiaan asumisen kohtuuhintaisuuden sekava tila heijastaa Suomen asuntopolitiikan irrallisuutta hyvinvointivaltion kokonaisuudesta (vrt. Juntto 1990; Hyötyläinen 2019, 40). Tällä hetkellä asumista käsitellään erillään kotitalouksien tulokehityksestä tai sosiaaliturvasta. Asiaa selventäisi kotitalouksien tulojen, asumismenojen ja asumistarpeiden vuorovaikutukseen perustuvan normatiivisen näkökulman ottaminen vakavasti. Suomessa on esimerkiksi aiemmin havaittu, että asumismenojen huomiointi muuttaa pienituloisuuden kuvaa (Ilmarinen \& Kauppinen 2018). Näkökulmaa soveltamalla asuminen voitaisiin huomioida nykyistä paremmin osana yhtälöä, johon kuuluvat kaupungistumiseen, työllisyyteen, tuloihin ja asumismenoihin, asumistasoon ja eriarvoisuuteen liittyvät tekijät.

Tutkimusta ovat rahoittaneet Turun kaupunkitutkimusohjelma ja Länsi-Suomen yleishyödyllinen asuntosäätiö (Kohtuuhintaisen asumisen pullonkaulat ja ratkaisut -tutkimushanke) sekä Suomen Akatemian Strategisen tutkimuksen neuvosto, STN (Kestävää kaupungistumista maankäytön ohjauksen keinoin, SmartLand, päätösnumero 327800, osahanke 327801).

\section{KIRJALLISUUS}

Anacker, Katrin (2019). Introduction: Housing affordability and affordable housing. International Journal of Housing Policy 19:1, 1-16. https://doi.org/10-1080/19491247-2018-1560544

Andersson, Elisabeth (1993). Value in ethics and economics. Harvard University Press, Cambridge.

Antikainen, Janne \& Laakso, Seppo \& Lönnqvist, Henrik \& Pyykkönen, Sinikukka \& Soininvaara, Ilppo (2017). Asuntopolitiikan kehittämiskohteita. Eduskunnan Tarkastusvaliokunnan julkaisu 1/2017. Eduskunta, Helsinki.

Aravarajoituslaki 119o/1993. Edita Publishing Oy. [viitattu 10.12.2019] <https://www.finlex.fi/fi/laki/ smur/1993/19931190>

Asumisen rahoitus- ja kehittämiskeskus (ARA) (2016). ARAn strategia 2016-2020. Asumisen rahoitus- ja kehittämiskeskus ARA. [viitattu 4.1.2020] <https://www.ara.fi/fi-FI/ARA/ Toimintaajatus_arvot_ja_visio>

ARA (2018). Vuokranmääritysopas arava- ja korkotukivuokra-asuntoihin. Asumisen rahoitus- ja kehittämiskeskus, Lahti.

ARA (2019a). Lyhytaikainen korkotukilaina vuokratalojen rakentamiseen 2019. Hakuohje. Asumisen rahoitus- ja kehittämiskeskus, Lahti.

ARA (2019b). Asumisen rahoitus- ja kehittämiskeskuksen tulostavoitteet vuosille 2016-2019. Päivitys vuodelle 2019. VN/787/2019.

ARA (2019c). Asumisen rahoitus- ja kehittämiskeskuksen (ARA) näkemyksiä asuntopolitiikan kehittämiskohteisiin. Asumisen rahoitus- ja kehittämiskeskus ARA. [viitattu 4.1.2020] <https://www.ara.fi/fi-FI/Ajankohtaista/Uutiset_ja_tiedotteet/Uutiset_ja_tiedotteet_2019/ aran_nakemyksia_asuntopolitiikan_kehitta(49755)>

Bramley, Glen (1994). An affordability crisis in British housing: Dimensions, causes and policy impact. Housing Studies 9:1, 103-124. https://doi.org/10-1080/02673039408720777

Bramley, Glen (2012). Affordability, poverty and housing need: triangulating measures and standards. Journal of Housing and the Built Environment 27:2, 133-51. https://doi.org/10-1007/s10901-011-9255-4 
Czischke, Darinka \& van Bortel, Gerard (2018). An exploration of concepts and policies on 'affordable housing' in England, Italy, Poland and the Netherlands. Journal of Housing and the Built Environment. https://doi.org/10-1007/s10901-018-9598-1

Doling, John (1997). Comparative housing policy. Government and housing in advanced industrialized countries. Lontoo, MacMillan Press Ltd. https://doi.org/10-1007/978-1-349-25878-9

Eerola, Essi \& Lyytikäinen, Teemu \& Saarimaa, Tuukka (2012). Asuntomarkkinat ja muuttoliike - mistä asumisen hintaerot kertovat? Teoksessa Loikkanen, Heikki \& Laakso, Seppo \& Susiluoto, Ilkka (toim.): Metropolialueen talous: Näkökulmia kaupunkitalouden ajankohtaisiin aiheisiin. Helsingin kaupungin tietokeskus, Helsinki

Eurostat (2014). Glossary: housing cost overburden rate. European Comission. [viitattu 17.1.2020] <https:// ec.europa.eu/eurostat/statistics-explained/index.php/Glossary:Housing_cost_overburden_rate>

Ezennia, Ikenna \& Hoskara, Sebnem (2019). Methodological weaknesses in the measurement approaches and concept of housing affordability used in housing research: A qualitative study. PLoS ONE 14: 8, 1-27. https://doi.org/10-1371/journal.pone.0221246

FEANTSA \& Fondation Abbé Pierre (2019). Fourth overview of housing exclusion in Europe. FEANTSA, Bryssel.

Gabriel, Michelle \& Jacobs, Keith \& Arthurson, Kathy \& Burke, Terry \& Yates, Judith (2005). Conceptualising and measuring the housing affordability problem. Research paper 1. Melbourne, Australian housing and urban research institute (AHURI).

Gabriel, Stuart \& Painter, Gary (2020). Why affordability matters. Regional Science and Urban Economics 80:January 2020, 103378. https://doi.org/10-1016/j.regsciurbeco.2018-07-001

Glaeser, Edward \& Gyourko, Joseph (2003). The impact of building restrictions on housing affordability. FRBNY Economic Policy Review June 2003, 21-39.

Granath Hansson, Anna \& Lundgren, Björn (2018). Defining social housing: A discussion on the suitable criteria. Housing, theory and society $36: 2,149-166$. https://doi.org/10-1080/14036096-2018-1459826

Haffner, Marietta \& Heylen, Kristof (2011). User costs and housing expenses. Towards a more comprehensive approach to affordability. Housing Studies 26:4, 593-614. https://doi. org/10-1080/02673037-2011-559754

Haila, Anne (2015). Kymmenen asuntopolitiikan myyttiä. Yhteiskuntapolitiikka 80:3, 283-291.

Hallituksen esitys eduskunnalle uusiksi huoneenvuokralaeiksi ja niihin liittyvien lakien muuttamisesta. HE $304 / 1994 \mathrm{vp}$.

Hallituksen esitys eduskunnalle laiksi toimeentulotuesta sekä laiksi sosiaalihuoltolain ja -asetuksen eräiden säännösten kumoamisesta HE 217/1997 vp.

Hallituksen esitys eduskunnalle vuokra-asuntolainojen ja asumisoikeustalolainojen korkotukea koskevaksi lainsäädännöksi HE 181/2000 vp.

Hallituksen esitys eduskunnalle kansaneläkelaiksi, laiksi vammaisetuuksista ja laiksi eläkkeensaajan asumistuesta sekä eräiksi niihin liittyviksi laeiksi HE 9o/2006 vp.

Hallituksen esitys eduskunnalle laeiksi yleisestä asumistuesta ja eläkkeensaajan asumistuesta annetun lain muuttamisesta HE 52/2014 vp.

Hancock, K. E. (1993). 'Can pay? Won't pay?' Or economic principles of 'affordability.' Urban Studies 30:1, 127-45. https://doi.org/10-1080/00420989320080081

Helsingin kaupunki (2016). Kotikaupunkina Helsinki. Asumisen ja siihen liittyvän maankäytön toteutusohjelma 2016. Helsingin kaupungin keskushallinnon julkaisuja 2016: 19. Helsingin kaupunginkanslia, Helsinki.

Hulchanski, David (1995): The concept of housing affordability: Six contemporary uses of the housing expenditure-to-income ratio. Housing studies 10:4, 471-491. https://doi. org/10-1080/02673039508720833

Huhtala, Ville-Valtteri \& Kekäläinen, Antti \& Noro, Kirsi (2017): Asumisen tuet vuokralaisen näkökulmasta. PTT raportteja 257. Helsinki, Pellervon taloustutkimuskeskus.

Hyötyläinen, Mika (2019). Divided by policy: Urban inequality in Finland. Helsingin yliopisto. Helsinki.

Ilmarinen, Katja \& Kauppinen, Timo (2018). Pienituloisuus ennen ja jälkeen asumiskustannuksia alueellinen näkökulma. Yhteiskuntapolitiikka 83:1, 73-83. 
Juntto, Anneli (1990). Asuntokysymys Suomessa Topeliuksesta tulopolitiikkaan. Valtion painatuskeskus, Helsinki.

Juntto, Anneli (2001). Miksi pääkaupunkiseutua vaivaa toistuva asuntopula? Yhteiskuntasuunnittelu 39:3, 51-61.

Kauppinen, Timo \& Hannikainen-Ingman, Katri \& Sallila, Seppo \& Viitanen, Veera (2015). Pienituloisten asuinolot. Terveyden ja Hyvinvoinnin laitos, Helsinki.

Kela (2018). Toimeentulotuen vuokranormit. Julkaisematon muistio. Kansaneläkelaitos, Helsinki.

Kela (2019): Asumistukimenot uuteen ennätykseen vuonna 2018. Tilastokatsaus $4 / 2019$. Kansaneläkelaitos, Helsinki[viitattu 15.4.2020] < https://helda.helsinki.fi/bitstream/handle/10138/299692/ Asumistukimenot_uuteen_ennatykseen_vuonna\%202019.pdf? sequence=1\&isAllowed=y >

Kela (2020). Perustoimeentulotuessa hyväksyttävien vuokramenojen kuntakohtaiset rajat 2020. Kansaneläkelaitos. [viitattu 15.1.2020] 〈https://www.kela.fi/documents/10180/o/Toimeentulotuki asumismenojen \%2orajat_2o2o suomenkielinen.pdf/44641bg8-b45o-4f 52 -af 25 -ocfg1caa86c7.. >

Kettunen, Hanna \& Ruonavaara, Hannu (2015). Discoursing deregulation: The case of the Finnish rental housing market. International Journal of Housing Policy 15:2, 187-204. https://doi. org/10-1080/14616718-2014-990774

Kortteinen, Matti \& Vaattovaara, Mari (2015). Segregaation Aika. Yhteiskuntapolitiikka 80:6, 562-574.

Kuntalaki 410/2015. Edita Publishing Oy. [viitattu 10.12.2019] <https://www.finlex.fi/fi/laki/ smur/2015/20150410>

Laakso, Seppo \& Loikkanen, Heikki (2004). Kaupunkitalous. Johdatus kaupungistumiseen, kaupunkien maankäyttöön sekä yritysten ja kotitalouksien sijoittumiseen. Gaudeamus, Helsinki.

Laki asuinhuoneiston vuokrauksesta 481/1995. Edita Publishing Oy. [viitattu 10.12.2019] <https://www. finlex.fi/fi/laki/smur/1995/19950481>

Laki toimeentulotuesta 1412/1997. Edita Publishing Oy. [viitattu 10.12.2019] < https://www.finlex.fi/fi/laki/ smur/1997/19971412>

Laki vuokra-asuntolainojen ja asumisoikeustalolainojen korkotuesta 604/2001. Edita Publishing Oy. [viitattu 10.12.2019] 〈https://www.finlex.fi/fi/laki/smur/2001/20010604〉

Laki eläkkeensaajan asumistuesta 571/2007. Edita Publishing Oy. [viitattu 10.12.2019] <https://www.finlex. fi/fi/laki/smur/2007/20070571>

Laki yleisestä asumistuesta 938/2014. Edita Publishing Oy. [viitattu 10.12.2019] <https://www.finlex.fi/fi/ laki/smur/2014/20140938>

Laki vuokratalojen rakentamislainojen lyhytaikaisesta korkotuesta 574/2016. Edita Publishing Oy. [viitattu 10.12.2019] 〈https://www.finlex.fi/fi/laki/smur/2016/20160574〉

Lehtinen, Anna-Riitta \& Aalto, Kristiina (2018). Mitä eläminen maksaa? Kohtuullisen minimin viitebudjettien päivitys vuodelle 2018. Valtiotieteellisen tiedekunnan julkaisuja 101/2018. Helsingin yliopisto, Helsinki. https://doi.org/10-31885/9789515133588

Maankäyttö- ja rakennuslaki 132/1999. Edita Publishing Oy. [viitattu 10.12.2019] <https://www.finlex.fi/fi/ laki/smur/1999/19990132>

MacIennan, Duncan \& Williams, R. U. (1990). Affordable Housing in Britain and the United States. Joseph Rowntree Foundation, York.

Madden, David \& Marcuse, Peter (2016) In Defense of Housing. The Politics of Crisis. Verso, Lontoo ja New York.

Matala, Timo (2018): Asumistuet selvässä kasvussa viimeiset kymmenen vuotta. Tieto \& Trendit 28.8.2018. Tilastokeskus, Helsinki. Verkkojulkaisu [viitattu 16.4.2020] <https://www.stat.fi/tietotrendit/ artikkelit/2018/asumistuet-selvassa-kasvussa-viimeiset-kymmenen-vuotta/>

Mukkila, Susanna \& Saikkonen, Paula (2018). Asumisen hinta heikentää kohtuullisen kulutuksen mahdollisuuksia Helsingissä. Tackling Inequalities in Time of Austerity (TITA) Policy Brief 3/2018. Turun yliopisto, Turku.

OECD (2019). Under pressure: the squeezed middle class. OECD Publishing, Pariisi. https://doi. org/10-1787/689afed1-en 
Oxley, Michael (2012). Supply-side subsidies for affordable rental housing. Teoksessa Smith, Susan J. (toim.): Elsevier Encyclopaedia of Housing and Home. Elsevier Science. https://doi.org/10-1016/ B978-0-08-047163-1.00419-7

Quigley, John M. \& Raphael, Steven (2004). Is housing unaffordable? Why isn't it more affordable? Journal of Economic Perspectives 18:1, 191-214. https://doi.org/10-1257/089533004773563494

Padley, Matt \& Marshall, Lydia (2019). Defining and measuring housing affordability using the minimum income standard. Housing Studies 34:8, 1307-1329. https://doi.org/10-1080/02673037-2018-1538447

Ruonavaara, Hannu (2013). Finland - den dualistiska bostadsregimen och jakten på det sociala. Teoksessa Bengtsson, Bo \& Annaniassen, Erling \& Jenssen, Lotte \& Ruonavaara, Hannu \& Sveinsson, Jón Rúnar (toim.): Varför so olika? Nordisk bostadspolitik i jämförande historiskt ljus. Égalité, Århus.

Ruonavaara, Hannu (2017). Retrenchment and social housing: The case of Finland. Critical Housing Analysis 4:2, 8-18. https://doi.org/10-1306o/23362839-2017-4.2-382

Saikkonen, Paula \& Hannikainen, Katri \& Kauppinen, Timo \& Rasinkangas, Jarkko \& Vaalavuo, Maria (2018). Sosiaalinen Kestävyys: Asuminen, segregaatio ja tuloerot kolmella kaupunkiseudulla. Raportti 2/2018. Terveyden ja hyvinvoinnin laitos, Helsinki.

Smith, Janet (2012). Access and affordability: Developed countries. Teoksessa Smith, Susan J. (toim.): Elsevier Encyclopaedia of Housing and Home. Elsevier Science. https://doi.org/10-1016/ B978-0-08-047163-1.00009-6

Stone, Michael (2006). What is housing affordability? The case for the residual income approach. Housing Policy Debate 17:1, 151-84. https://doi.org/10-1080/10511482-2006-9521564

Stone, Michael \& Burke, Terry \& Ralston, Liss (2011). The residual income approach to housing affordability: The theory and the practice. AHURI Positioning Paper No. 139. Australian Housing and Urban Research Institute (AHURI), Melbourne

Suomen perustuslaki 731/1999. Edita Publishing Oy. [viitattu 10.12.2019] <https://www.finlex.fi/fi/laki/ smur/1999/19990731>

Suomen virallinen tilasto (SVT) (2019): Asunnot ja asuinolot [verkkojulkaisu]. Yleiskatsaus 2018, 2. Asuntokunnat ja asuinolot 2018. Tilastokeskus, Helsinki. [viitattu 15.4.2020]. <http://www.stat.fi/til/ asas/2018/01/asas_2018_01_2019-10-10_kat_002_fi.html>

Suomen virallinen tilasto (SVT) (2020): Tulonjakotilasto [verkkojulkaisu]. Tilastokeskus, Helsinki. [viitattu 9.4.2020] <http://www.stat.fi/til/tjt/>

Tampereen kaupunki (2018). Asunto- ja maapolitiikan linjaukset 2018-2021. Tampereen kaupunki. [viitattu 4.1.2020] < https://www.tampere.fi/tiedostot/a/scUlegNWl/Asunto_ja_maapolitiikan_ linjaukset_2018_2021.pdf>

Tampereen kaupunkiseutu (2016). Valtion ja Tampereen kaupunkiseudun kuntien välinen maankäytön, asumisen ja liikenteen sopimus 2016-2019. YM10/5511/2016.

Tarkastusvaliokunta (2018). Asuntopolitiikan kehittämiskohteet. Valiokunnan mietintö trvm32018 vp - O $61 / 2016 \mathrm{vp}$

Torgensen, U. (1987). Housing: The wobbly pillar under the welfare state. Teoksessa Turner, J. K. B. \& Lundquist, L. (toim.): Between state and market: Housing in the post-industrial era. Tukholma, Almqvist \& Wiksell, 116-126. https://doi.org/10-1080/02815737-1987-10801428

UN Habitat (2009). The right to adequate housing. Fact Sheet No. 21/Rev.1. Office of the United Nations High Commissioner for Human Rights, Geneva

Valtioneuvosto (2007). Pääministeri Matti Vanhasen II hallituksen ohjelma. Valtioneuvoston kanslia, Helsinki

Valtioneuvosto (2010). Valtioneuvoston tiedonanto Eduskunnalle 22.6.2010 nimitetyn pääministeri Mari Kiviniemen hallituksen ohjelmasta. Valtioneuvoston kanslia. [viitattu 1.12.2019] <https:// valtioneuvosto.fi/documents/10184/367816/hallitusohjelma-kiviniemi.pdf/4eceo8eb-c703-4bco-ac36ab93езаоо6о7/hallitusohjelma-kiviniemi.pdf>

Valtioneuvosto (2011). Pääministeri Jyrki Kataisen hallituksen ohjelma. Hallituksen julkaisusarja 1/2011. Valtioneuvoston kanslia, Helsinki.

Valtioneuvosto (2012). Valtioneuvoston asuntopoliittinen ohjelma vuosille 2012-2015. Valtioneuvoston kanslia, Helsinki. 
Valtioneuvosto (2014). Valtioneuvoston tiedonanto eduskunnalle 24.6.2014 nimitetyn pääministeri Alexander Stubbin hallituksen ohjelmasta. Valtioneuvoston kanslia, Helsinki.

Valtioneuvosto (2018). Kestävää elinympäristöä rakentamassa. Ympäristöministeriön tulevaisuuskatsaus 2030. Valtioneuvoston julkaisusarja 15/2018. Valtioneuvoston kanslia, Helsinki.

Valtioneuvosto (2019a). Pääministeri Antti Rinteen hallituksen ohjelma 6.6.2019. Valtioneuvoston julkaisuja 2019:23. Valtioneuvoston kanslia, Helsinki.

Valtioneuvosto (2019b). Pääministeri Sanna Marinin ohjelma 10.12.2019. Valtioneuvoston julkaisuja 2019:31. Valtioneuvoston kanslia, Helsinki.

Valtioneuvoston kanslia (2015). Ratkaisujen Suomi. Pääministeri Juha Sipilän hallituksen strateginen ohjelma 29.5.2015. Hallituksen julkaisusarja 10/2015. Valtioneuvoston kanslia, Helsinki.

Valtioneuvoston asetus eläkkeensaajan asumistuen määräytymisperusteista vuonna 2019 910/2018. Edita Publishing Oy. [viitattu 10.12.2019] <https://www.finlex.fi/fi/laki/smur/2018/20180910〉

Whitehead, Christine (1991). From need to affordability: An analysis of UK housing objectives. Urban Studies 28:6, 871-87. https://doi.org/10-1080/00420989120081101

Ympäristöministeriö (YM) (2008). Hallituksen asuntopoliittiset ohjelmat. Ympäristöministeriön raportteja 15/2008. Ympäristöministeriö, Helsinki.

Ympäristöministeriö (2016a). Valtion ja Helsingin seudun välinen maankäytön, asumisen ja liikenteen sopimus 2016--2019. YM19/5511/2015.

Ympäristöministeriö (2016b). Valtion ja Turun kaupunkiseudun kuntien välinen maankäytön, asumisen ja liikenteen sopimus 2016--2019. YM11/5511/2016.

Ympäristöministeriö, YM (2018a). Strategia 2030. Ympäristöministeriö. [viitattu 4.1.2020] <https://www. ym.fi/download/noname/\%7B4ABFDoF8-6476-4B40-878F-259AoB98C6Co\%7D/137607〉

Ympäristöministeriö, YM (2018b). Strategian toimenpidepolut. Ympäristöministeriö. [viitattu 4.1.2020] 〈https://www.ym.fi/fi-FI/Ministerio/Tavoitteet_ja_tulokset/Strategia_2030〉

Ympäristöministeriö, YM (2019a). Ympäristöministeriön strateginen tulossopimus 2020. Ympäristöministeriö. [viitattu 27.1.202o] <https://www.ym.fi/fi-FI/Ministerio/Tavoitteet_ja_tulokset/ Suunnittelun_ja_seurannan_asiakirjat $>$

Ympäristöministeriö (2019b). Talousarvioesitys 2020. Ministeriön ehdotus. Pääluokka 35: Ympäristöministeriön hallinnonala. Ympäristöministeriö. [viitattu 27.1.2020] <http://www.ym.fi/ download/noname/\%7BC6AFCF49-56C3-458E-8306-E48FE6A4A6D1\%7D/148699>

Ympäristöministeriö (2019c). Ympäristöministeriön tilinpäätös 2018. Ympäristöministeriön julkaisuja 2019: 6. Ympäristöministeriö, Helsinki. 